\title{
Chemical Preservation Methods of Urine Sediment for Quality Control
}

\author{
Soung Suck Cho ${ }^{1}$, Myong Soo Kim², Kyung-A Shin ${ }^{1}$ \\ ${ }^{1}$ Department of Clinical Laboratory Science, Shinsung University, Dangjin, Korea \\ ${ }^{2}$ Department of Laboratory Medicine, Samsung Medical Center, Seoul, Korea
}

\section{정도관리를 위한 요침사의 화학적 보존방법}

\author{
조성석 ${ }^{1}$, 김명수 ${ }^{2}$, 신경아 $^{1}$ \\ ${ }^{1}$ 신성대학교 임상병리과, ${ }^{2}$ 삼성서울병원 진단검사의학과
}

\begin{abstract}
There is greater standardization of quality control for microscopic examination of urine than for physicochemical test. In this study, we investigated whether it is possible to control the sediment accuracy by microscopic examination through the real thing by preserving the essential sediment with glutaraldehyde, which is required for the rationality of sediment quality control. A urine specimen was prepared using $2.5 \%$ glutaraldehyde as a preservation solution. Samples treated with urine preservatives confirmed the morphological deformation of the cells for four weeks at intervals of one week and confirmed whether they should be preserved for 4 weeks thereafter. After preparing the required sediment slide, two more slides were produced; one was stored in a refrigerator for, and the other was stored at room temperature. The morphological deformation of the specimen was confirmed. Glutaraldehyde has the effect of preserving the refrigerated essential sediments and storing them for up to 8 weeks, refrigerated storage after slide production, stabilized by 3 days. Moreover, after treatment with preservatives, the production of the slide and comparison between the measured values between the laboratories and examiners showed a low consistency. In conclusion, we showed that the urine sediment components can be preserved, and it can be used for quality control and education through real objects.
\end{abstract}

Key words: Glutaraldehyde, Microscopic examination, Urine preservative

This is an Open Access article distributed under the terms of the Creative Commons Attribution Non-Commercial License (http://creativecommons.org/licenses/by-nc/4.0) which permits unrestricted non-commercial use, distribution, and reproduction in any medium, provided the original work is properly cited.

Copyright $\odot 2017$ The Korean Society for Clinical Laboratory Science. All rights reserved. 
상도와 관련된 문제점, 표본 전체를 평가할 수 없는 문제점, 실 제 병원에서의 결과 보고방식을 반영하지 못하는 제한점을 가 지고 있다.

요침사 보존과 관련하여 오래전부터 봉입제나 보존제로 요 침사 표본을 장기간 보존하는 방법이 활용되고 있으며, 이들은 오늘날 현미경적 검사의 발전에 크게 기여하였다[6,8-11]. 그 러나 요침사 표본은 장기간 보존이 어렵고 병리학적 기법을 응 용하여 특정 성분만을 표본으로 저장할 수 있는 방법이 보고되 고 있지만, 전체 요침사 성분을 표본으로 저장하는 방법은 확립 되어 있지 않다[9]. Komarova 등[8]은 포름알데히드 기반의 고 정액으로 24 시간 동안 요침사의 형태학적 보존이 가능하며, 이 는 임상 실습용으로 활용할 수 있다고 보고하였다. 또한 Anpalahan 등[10]의 연구에서는 글루타르알데히드와 포름알 데히드로 요침사를 고정한 후 최대 3개월 동안 실온에서 보관한 후에도 위상차 현미경 검사를 수행 할 수 있다고 보고하고 있어, 요침사 보존을 통해 교육용 슬라이드 제작이나 일부 검사실간 외부정도관리 시행의 필요성이 요구된다. 특히 글루타르알데 히드는 세포 용해(cellular lysis)를 방지하며, 적혈구 보존에 유 용한 것으로 보고된다[11,12]. 이를 뒷받침할 근거로 글루타르 알데히드를 화학적 보존제로 사용한 결과 요침사 분석에 효과 적이고 적합하다는 결과가 보고되었다[11]. 실제 요침사를 표 본으로 장기간 보존이 가능하다면 동일한 표본을 이용하여 반 복 교차확인을 통해 내·외부정도관리에 기여함과 동시에 교육 적 효과가 있을 것으로 기대된다[9]. 이에 본 연구에서는 글루타 르알데히드 요침사 보존제를 이용하여 요침사 보존효과와 보존 기간을 확인하고, 보존 요침사액을 이용하여 슬라이드를 제작 하여 실제적인 현미경 검사에 의한 담당자간 판독 교차확인 및 검사실간 비교가 가능한지를 검토해보고자 하였다.

\section{대상 및 방법}

\section{1. 연구 대상}

연구 대상이 되는 검체는 서울 S병원에서 Sysmex UF-1000i (Sysmex, Kobe, Japan)로 요침사 검사를 시행하여 요침사 결 과 중 이상 검체를 육안 현미경 검사로 재확인한 후 연구 대상으 로 선정하였으며, 총 25 개 검체를 대상으로 하였다. 또한 측정 요침사 성분은 백혈구, 적혈구(변형 적혈구), 상피세포, 원주, 결 정성분이었으며, 이 중 결정성분은 옥살산칼슘을 포함하여 5종 을 대상으로 하였다.

\section{2. 요침사 제작}

요침사 제작방법은 신선 중간 소변을 conical tube에 $10 \mathrm{~mL}$ 분주하여 5 분간 원심분리 $(500 \mathrm{xg})$ 하였다. 원심분리 후 상층액 은 버리고 $0.5 \mathrm{~mL}$ 가량 침전물을 얻게 되는데, 여기에 글루타르 알데히드 20 50 uL 첨가하였다. 글루타르알데히드와 침전물, 상층 여액을 함께 가볍게 혼합하여 파이펫을 이용하여 슬라이 드에 $0.01 \mathrm{~mL}$ 떨어뜨린 후 cover glass를 덮고 광학현미경으로 관찰하였다. 글루타르알데히드 요침사 보존제는 $25 \%$ 글루타르 알데히드 $10 \mathrm{~mL}$ 에 증류수 $90 \mathrm{~mL}$ 를 혼합하여(2.5\% 글루타르알 데히드) 이를 보존액으로 하여 표본을 제작하였다[11].

\section{3. 요침사 보존}

요침사 보존효과 확인은 동일 검체 2개를 원심분리 후 하나는 보존제 처리하고 다른 하나는 보존제를 처리하지 않은 상태로 냉 장보관 후 결과를 비교하였다. Clinical and Laboratory Standards Institute 지침(CLSI GP16-A3)에 따르면 요침사 검 사와 계산을 위해 counts/mL로 보고하는 것을 권장하고 있다 [13]. 그러나 본 연구에서 요침사 보존여부는 검사실에서 일반적 으로 시행하는 현미경으로 100배 저배율(low power field, $\mathrm{LPF}$ )에서 전체 시야를 관찰한 후 400배 고배율(high power field, $\mathrm{HPF}$ )에서 10 시야 이상 관찰하여 요침사 성분의 종류와 세 포수의 평균치를 측정하였으며[13], 세포의 형태학적 변형을 확 인 후사진으로 기록하여 평가하였다. 보존제를 처리한 검체는 1 주일 간격으로 4주간 세포의 형태학적 변형을 확인하였고, 이후 4 주간은 보존여부를 확인하였다. 연구과정에서 요침사 보존여 부는 동일한 임상병리사에 의해 육안 현미경 관찰 후 사진을 촬 영하여 비교하였으며, 세포의 형태학적 변화를 확인하였다.

\section{4. 슬라이드 제작 후 보존효과 확인}

요침사 슬라이드 제작 후 MEISEI auto slide coverslipping (RCM 7000, Tokyo, Japan) 장비를 이용하여 Consul-Mount (Thermo Fisher Scientific, Madison, USA)로 검체 당 2개의 슬라이드를 제작하였으며, 하나는 냉장보관, 다른 하나는 실온 보관하여 검체의 형태학적 변형을 확인 후 사진으로 기록하여 평가하였다.

\section{5. 정도관리 시행}

담당자간 판독 교차 확인은 변형 적혈구 검체로 슬라이드를 제작하여 1 기관에서 담당자간 판독 교차 확인을 시행하였다. 검 사실간 비교는 변형 적혈구 및 일반 이상 검체로 슬라이드를 제 
작하여 변형 적혈구는 7 기관, 일반 이상 검체는 10 기관에서 검 사실간 비교를 시행하였다. 요침사 슬라이드 제작 후 냉장 보관 하여 3일간 안정한 것이 확인되었으며, 담당자간 판독 교차 확 인 및 검사실간 비교에 사용된 검체는 보존제 처리하여 슬라이 드 제작 후 3일간 냉장 보관된 표본으로 시행하였다. 변형 적혈 구는 신장내과 환자의 검체로 비중이 1.010 이상이며, 광학현 미경의 고배율 $(\mathrm{HPF})$ 에서 5 개 이상의 적혈구가 관찰된 검체를 선정하여 백분율로 표시하였다. 백분율은 위상차 현미경으로 400 배 시야에서 100 개의 적혈구를 관찰하여 그 중 변형 적혈구 의 수를 세어 백분율로 구하였다. CLSI GP16-A3 지침에 따르 면 요침사 검사의 검사실간 결과 비교시 현미경의 고배율이나 저배율 시야당 결과 대신 용적단위당 비정상 요침사 성분을 보

Table 1. Preservation of urine sediment constituents after glutaraldehyde treatment

\begin{tabular}{lccccc}
\hline $\begin{array}{c}\text { Microscopic } \\
\text { elements }\end{array}$ & 1 week & 2 weeks & 3 weeks & 4 weeks & 8 weeks \\
\hline RBC & NC & NC & NC & NC & NC \\
WBC & NC & NC & NC & NC & NC \\
Epithelial cell & NC & NC & NC & NC & NC \\
Cast & NC & NC & NC & NC & NC \\
Crystal & NC & NC & NC & NC & NC \\
\hline
\end{tabular}

Abbreviations: WBC, white blood cell; RBC, red blood cell; NC, no change.
고하도록 제시하고 있으나, 이는 표준화된 상품화 시스템 사용 시 고려할 수 있다[13]. 그러므로 이 연구에서는 일반 이상 검체 의 검사실간 비교는 각 검사실의 보고방식에 따라 결과를 보고 하도록 하였다. 또한 보고된 결과의 cell grade 평가는 서울 $\mathrm{S}$ 병 원의 grade 1; 0 2(세포수/HPF), grade 2; 3 5(세포수/HPF), grade 3; 6 10 (세포수/HPF), grade 4; 11 20 (세포수/HPF), grade 5; >21 (세포수/HPF)을 기준으로 평가하였다.

\section{6. 설문조사}

기존에 정도관리협회에서 시행하고 있는 사진을 보고 판독 하는 방법의 문제점, 현재 연구하고 있는 슬라이드 실물을 보고 정도관리를 시행하는 방법의 문제점, 요경검 정도관리를 슬라 이드 실물로 실시하였을 경우의 장점을 설문지로 각 기관에 배 포하여 확인하였다.

\section{결 과}

요침사를 글루타르알데히드 보존제 처리 후 요침사 세포성 분의 보존 유무 및 기간을 확인한 결과 적혈구, 백혈구, 상피세 포, 원주, 결정성분은 글루타르알데히드에 의해 보존효과가 있 었으며, 글루타르알데히드 처리 후 냉장 보관하여 2개월까지 형 태학적 변화 없이 유지되었다(Table 1, Figure 1). 요침사를 글

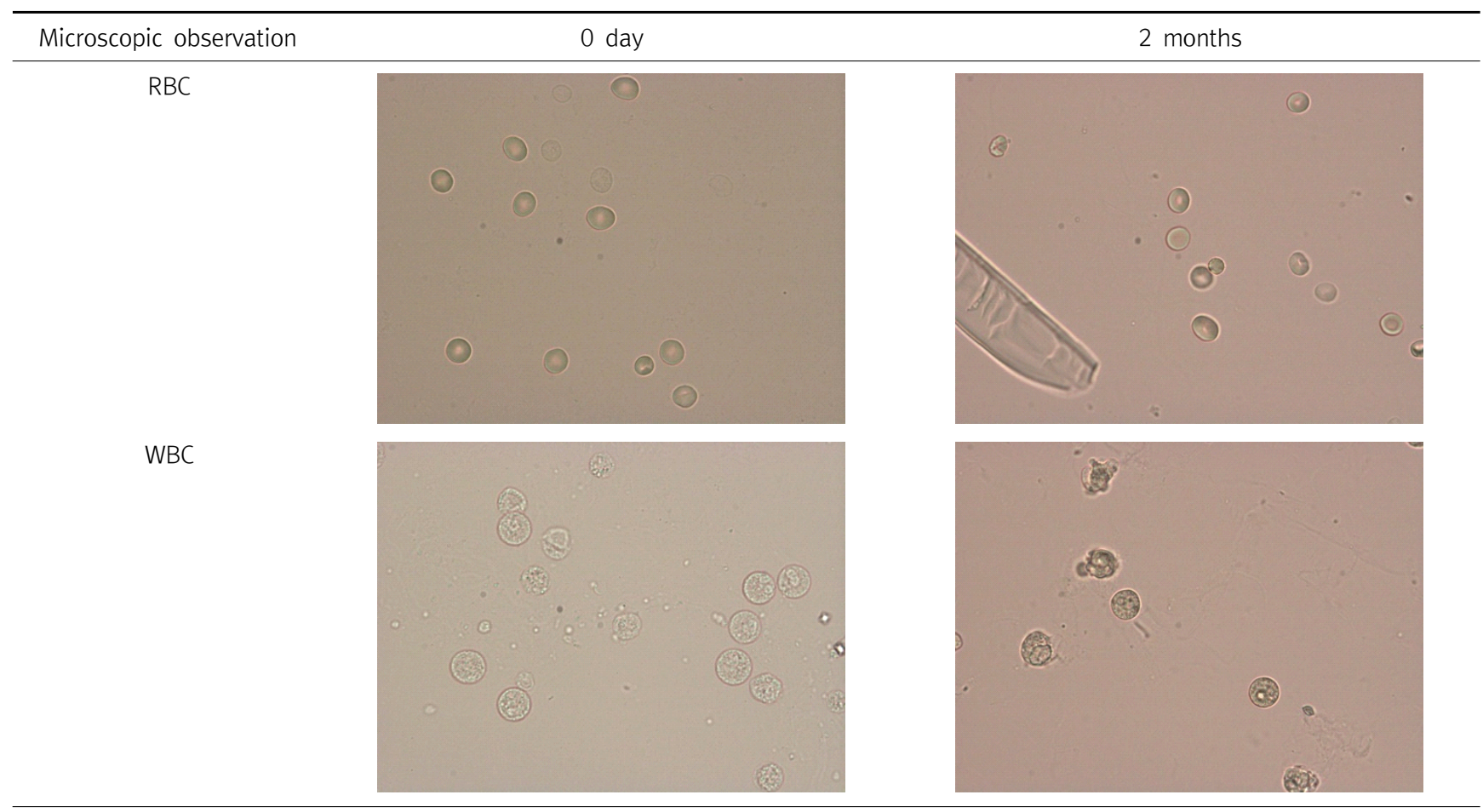

Figure 1. Morphological changes of urine sediment constituents after treatment with glutaraldehyde $(\times 400)$. Abbreviations: RBC, red blood cell; WBC, white blood cell. 


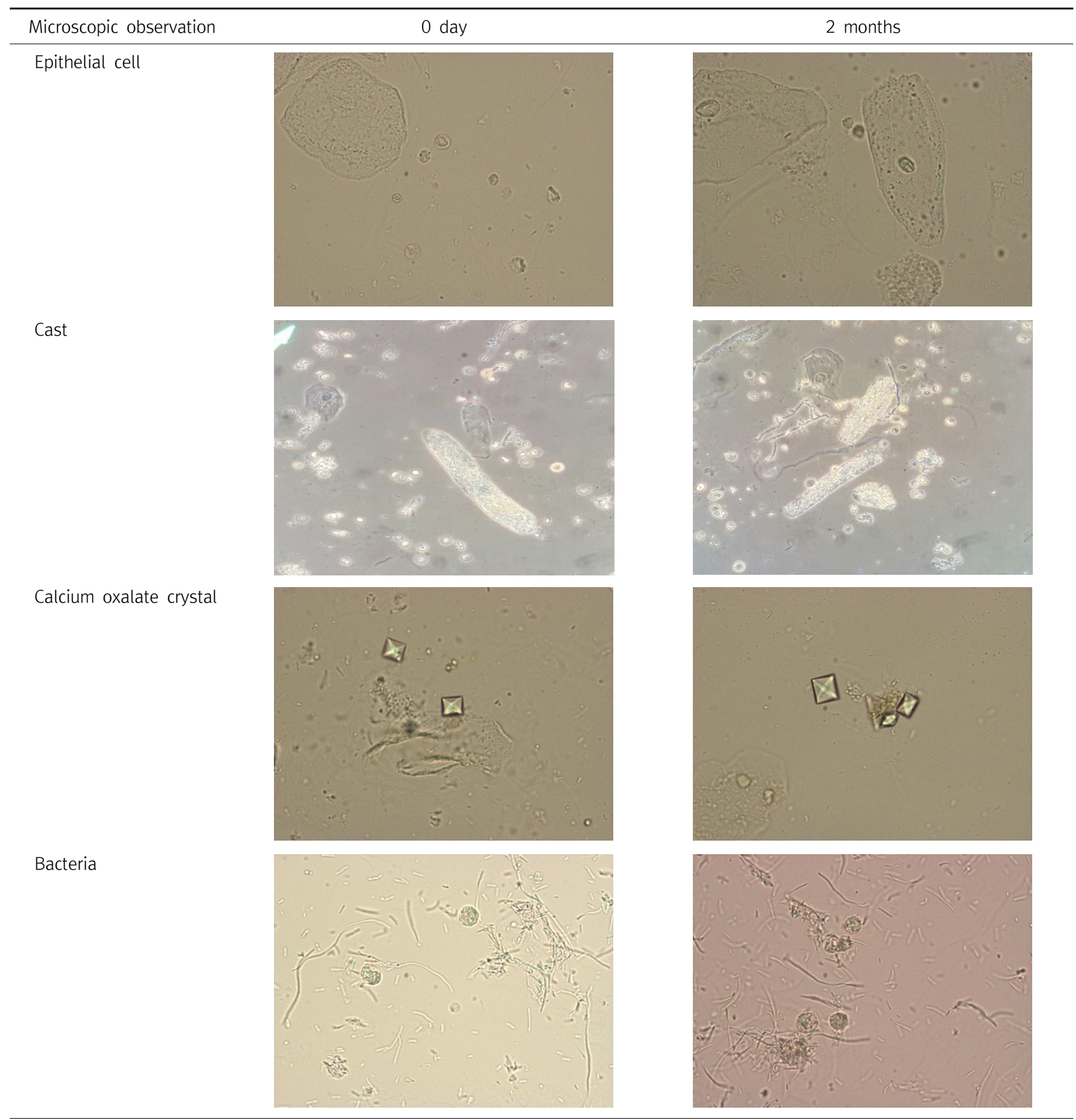

Figure 1. Continued.

루타르알데히드 처리 후 슬라이드를 제작하여 세포성분의 보존 을 확인한 결과 적혈구, 백혈구, 상피세포, 원주, 결정성분은 실 온에서 1일에 변화를 보였으나, 냉장 보관하였을 경우 세포 성 분들은 3일까지 안정한 것으로 나타났다(Table 2). 요침사를 글 루타르알데히드 처리 후 슬라이드 제작하여 변형 적혈구의 검 사실간, 검사자간 판독을 비교한 결과는 Table 3과 같다. 7 기관
의 검사실간 변형 적혈구 비율을 비교한 결과 $15 \sim 76 \%$ 로 편차 가 크게 나타났다. 또한 1 기관에서 3 명의 검사자간 변형 적혈구 비율을 판독 교차 확인한 결과 $40 \sim 70 \%$ 의 비율로 큰 편차를 보 였다. 일반 이상 검체로 요침사를 글루타르알데히드 처리 후 슬 라이드 제작하여 검사실간 판독을 비교한 결과 적혈구, 백혈구, 상피세포는 검사실간 일치도에 있어서 서울 $\mathrm{S}$ 병원의 기준에 따 
라 평가한 결과 cell grade가 1 2단계 정도의 차이를 보였으 며, $\mathrm{D}$ 병원에서는 적혈구만을 보고하였다. 또한 원주는 1 기관에 서 보고하였고 그 외의 다른 성분으로 세균은 4기관에서, 점액 사는 1 기관에서 보고하여 낮은 일치도를 보였다(Table 4). 설문 조사 결과 기존 정도관리협회에서 시행하는 사진을 통한 정도 관리 방법은 사진상으로 명확히 구분되지 않는 경우 $\mathrm{pH}$ 등 사진 에 대한 기본정보의 필요성, 사진의 해상도 문제로 명확히 구분 되지 않는 경우의 문제점이 조사되었다. 현재 연구하고 있는 슬 라이드 실물을 보고 정도관리를 시행한 결과 화살표 표기가 되 어 있지 않아 조사하고자 하는 대상이 명확하지 않은 점, 통일성 있는 슬라이드 제작이 어려운 점, 운송상태에 따라 드라이 및 기 포 발생 우려와같은 문제점이 조사되었다. 그러나 사진보다 현 업에 가까운 정도관리가 가능한 점, 사진에 비해 슬라이드 실물 이 더 명확해 관찰이 용이한 점, 여러 시야를 볼 수 있어 세포에 대한 혼동을 막을 수 있다는 장점이 설문지를 통해 보고되었다.

\section{고 찰}

요경검 검사는 검체가 검사실에 도착한 후 1 시간 이내의 신

Table 2. Preservation of the urine sediment constituents in urine slides after glutaraldehyde treatment

\begin{tabular}{lcccc}
\hline $\begin{array}{c}\text { Microscopic } \\
\text { elements }\end{array}$ & $\begin{array}{c}1 \text { day } \\
\text { at room } \\
\text { temperature }\end{array}$ & $\begin{array}{c}1 \text { day } \\
\text { refrigerated }\end{array}$ & $\begin{array}{c}2 \text { days } \\
\text { refrigerated }\end{array}$ & $\begin{array}{c}3 \text { days } \\
\text { refrigerated }\end{array}$ \\
\hline RBC & change & NC & NC & NC \\
WBC & change & NC & NC & NC \\
Epithelial cell & change & NC & NC & $N C$ \\
Cast & change & NC & NC & NC \\
Crystal & change & NC & NC & NC \\
\hline
\end{tabular}

Abbreviations: WBC, white blood cell; RBC, red blood cell; NC, no change.
선한 상태에서 시행되어야 하며, 검사가 종료된 검체는 보존되 지 않고 버려지고 있다[6]. 그러나 자주 볼 수 없는 세포 증례를 보존하거나, 신입직원 및 검사실 로테이션시 교육용 또는 학생 실습을 위한 교육용 자료로 보존하고자 하는 경우와 같이 요침 사를 장기간 보존해야 하는 필요성에도 불구하고 요침사 보존 에 관한 연구는 부족한 실정이다[6]. 본 연구에서는 요침사 정도 관리의 합리성을 위해 요침사 보존제인 글루타르알데히드로 요 침사를 보존하여 실물을 통한 현미경 검사로 요침사 정도관리 가 가능한지를 알아보고자 하였다.

CLSI GP16-A3 지침에 따르면 요검사는 채뇨 후 2 시간 이내 에 검사해야 하나 검사지연이 불가피한 경우 시료를 적절한 온 도에 보관하거나 보존제를 사용할 수 있다고 제시하고 있다 [13,14]. 그러나 일반적으로 요침사 보존제는 미생물 배양에서 주로 사용되고 있다[15]. 이전의 연구에서 고정액이나 염색방 법, 봉입물질 등을 사용하여 요침사를 장기간 보존하려는 시도 들이 있었다[6,8-11]. 그러나 이러한 염색법은 술식이 복잡하 고 염색법에 따라 세포의 형태가 명확하지 않으며[6], 병리학적 기법을 응용하여 특정 성분만을 표본으로 보존하는 방법이 보 고되고 있지만 전체 요침사 성분을 표본으로 보존하는 방법은

Table 3. Glutaraldehyde-treated slides compared between the laboratory and personnel of dysmorphic RBC

\begin{tabular}{ccc}
\hline Hospital & $\begin{array}{c}\text { comparison between } \\
\text { laboratories of } \\
\text { dysmorphic RBC }\end{array}$ & $\begin{array}{c}\text { comparison between } \\
\text { laboratory personnel } \\
\text { reading of dysmorphic RBC }\end{array}$ \\
\hline A & $35.0 \%$ & \\
B & $60.0 \%$ & \\
C & $15.0 \%$ & \\
D & $70.0 \%$ & \\
E & $76.0 \%$ & \\
F & $40.0 \%$ & $40.0 \%$ \\
G & $45.0 \%$ & $70.0 \%$ \\
\hline
\end{tabular}

Table 4. Compared between laboratories after glutaraldehyde slides produced

\begin{tabular}{|c|c|c|c|c|c|c|}
\hline Hospital & $\begin{array}{c}\mathrm{RBC} \\
\text { (cell/HPF) }\end{array}$ & $\begin{array}{c}\text { WBC } \\
\text { (cell/HPF) }\end{array}$ & $\begin{array}{l}\text { Epithelial cell } \\
\text { (cell/HPF) }\end{array}$ & Cast (cell/LPF) & Crystal (cell/LPF) & Others (cell/HPF) \\
\hline A & $10-19$ & $4-9$ & $0-3$ & +5 & ca. oxalate & \\
\hline B & $11-20$ & $6-10$ & $6-10$ & Hyaline cast/ > 21 & ca. oxalate/some & Bacteria/a few \\
\hline C & $5-9$ & $2-4$ & $5-9$ & . & ca. oxalate/some & Bacteria/a few \\
\hline D & $11-20$ & . & . & . & ca. oxalate/a few & . \\
\hline E & $5-9$ & $5-9$ & $5-9$ & . & & . \\
\hline $\mathrm{F}$ & $11-15$ & $3-5$ & $3-5$ & . & ca. oxalate/ $>20$ & . \\
\hline G & $10-19$ & $1-3$ & $1-3$ & . & ca. oxalate/10 19 & . \\
\hline $\mathrm{H}$ & $5-9$ & $5-9$ & $5-9$ & . & ca. oxalate/many/ $>10$ & Mucous thread, bacteria $2+$ \\
\hline I & $5-9$ & $10-19$ & $5-9$ & . & . & 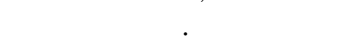 \\
\hline j & $5-9$ & $5-9$ & $1-4$ & . & ca. oxalate & Bacteria/a few \\
\hline
\end{tabular}

Abbreviations: RBC, red blood cel; WBC, white blood cell; HPF, high power field; LPF, low power field. 
확립되어 있지 않다[9]. 한편, 기존의 연구에서 화학적 보존제를 첨가 한 후 냉장 보관한 요침사는 세포성분의 보존에 효과가 있 는 것으로 보고되며[11], 최근에는 상품화된 요보존제 및 요보 존제 처리된 tube의 신뢰성을 평가하는 연구들이 보고되고 있 다[16,17].

본 연구에서는 글루타르알데히드 보존제를 사용하여 요침사 성분 중 적혈구, 백혈구, 상피세포, 원주, 결정성분의 형태학적 보존성을 확인하였으며, 냉장 보관하여 2개월간 세포성분의 변 형이 없는 것을 확인하였다. 요침사를 보존하기 위한 보존액으 로는 포름알데히드, 붕산(boric acid), 글루타르알데히드 등이 있다[8,10,11,18-20]. 붕산은 세균 발육 억제제로서 요침사 성 분 중 백혈구를 보존하는 것으로 알려져 있으며[20], 글루타르 알데히드는 일반적으로 $1.5 \sim 6 \%$ 의 수용액으로 조직과 세포를 보존하는 고정제로 사용된다[12]. 그 외에 전통적으로 에탄올 은 세포학에서 상피세포를 보존하는데 사용되지만, 부분적으 로 적혈구 및 백혈구의 용해를 방지한다[21]. 또한 폴리에틸렌 글리콜은 수축을 방지하고 보존효과를 향상시키기 위해 에탄올 고정제(Saccomanno's fixative)에 첨가된다[21]. Komarova 등[8]은 포름알데히드 기반의 고정액인 Cellfix를 통해 적어도 24시간 동안 요침사를 형태학적으로 보존하는 효과가 있어 임 상실습에 활용될 수 있음을 제시하였다. 요침사는 포름알데히 드와 글루타르알데히드 처리 후 냉장 보관하여 12시간 보존이 가능하며[11], Anpalahan 등[10]의 연구에서는 요침사를 포름 알데히드와 글루타르알데히드로 처리 후 실온에서 3개월간 보 존효과가 있어 위상차 현미경 검사가 가능함을 보고하였다. Bottini 등[22]도 포름알데히드계 용액을 사용하여 냉장에서 적 혈구 형태가 90 일까지 안정한 것을 보고하였다.

본 연구결과 요침사를 글루타르알데히드 처리 후 슬라이드 로 제작하여 세포성분의 보존을 확인한 결과 적혈구, 백혈구, 상 피세포, 원주, 결정성분은 실온에서 1일만에 변성을 보였으나, 냉장 보관하였을 경우 3 일까지 세포의 형태학적 변형이 없었다. 적혈구, 백혈구를 포함한 요침사세포성분은 $\mathrm{pH}$, 비중, 온도, 세 균의 존재 유무에 따라 형태학적으로 영향을 받으며, 세포의 붕 괴는 $\mathrm{pH}$ 7.0을 초과하거나 비중이 1.009 이하일 때 일어난다 [23]. 요침사 검사는 2 시간의 검사지연으로도 세포의 변형이 관 찰되는데 이는 스펙트린과 같은 단백질에 의해 유지되는 인지 질 이중층이 구조를 유지할 수 없기 때문이다[8].

저자들은 요침사 슬라이드 제작 후 냉장 보관하여 3일간 안 정한 것을 확인하였으며, 이를 통해 검사실간, 검사자간 판독을 비교하였다. 그 결과 7기관의 검사실간 변형 적혈구 비율은 15 $\sim 6 \%$ 로 편차가 크게 나타났다. 또한 1 기관에서 3 명의 검사자
간 변형 적혈구를 판독 교차 확인한 결과 40 70\%의 비율로 큰 편차를 보였다. 또한 일반 이상 검체로 슬라이드 제작하여 검사 실간 판독을 비교한 결과 적혈구, 백혈구, 상피세포는 검사실간 일치도에 있어서 cell grade가 1 2단계 정도의 차이를 보였다. 또한 원주는 1기관에서 보고하였고 그 외의 다른 성분으로 세균 은 4 기관에서, 점액사는 1 기관에서 보고하여 낮은 일치도를 보 였다. 이 같은 검사실간 일치도의 차이는 일부 슬라이드의 드라 이 현상, 표본제작에 있어서 bias, 검체농축의 영향 등이 결과에 영향을 미쳤을 가능성을 배제할 수 없으며, 이는 요경검 정도관 리를 슬라이드 실물로 실시하였을 때의 문제점으로 설문지를 통해 조사되었다. 향후 이러한 간섭현상을 방지할 수 있는 봉입 제 개발이 필요하겠다. 또한 본 연구에서는 10 기관간 결과 차이 를 비교하였으나 검사실과 검사자간의 판정기준에 의한 차이가 결과에 영향을 미쳤을 수 있으며, 이러한 제한점을 보완하여 요 경검에 있어서 객관적인 표준화된 시스템에 의한 추가 연구가 요구된다.

보존제의 종류와 보관 온도에 따라 요침사의 보존 기간은 다 양하다. 이러한 연구에도 불구하고 요침사 보존은 여전히 논란 의 여지가 많은 절차이며, 일상적으로 적용되지 않는다. 그러나 글루타르알데히드를 이용하여 저렴하고 간단한 방법으로 요침 사를 보존함으로서 내부정도관리에 응용이 가능하리라 생각된 다. 또한 평소 자주 볼 수 없는 세포의 증례를 포함하여 많은 요 침사 성분을 보존할 수 있으며, 학생실습 및 검사실에서 교육용 으로 활용될 것으로 기대된다[6].

결론적으로 글루타르알데히드는 요침사를 냉장 보관하여 2 개월까지 보존하는 효과가 있었으며, 슬라이드 제작 후에는 냉 장 보관하여 3일까지 안정한 것으로 나타났다. 또한 보존제 처 리 후 슬라이드 제작하여 검사실간, 검사자간 판독을 비교한 결 과 낮은 일치도를 보였다.

\section{요 약}

요침사 검사는 물리화학적 검사보다 정도관리의 표준화가 어려운 실정이다. 본 연구에서는 요침사 정도관리의 합리성을 위해 요침사 보존제인 글루타르알데히드로 요침사를 보존하여 실물을 통한 현미경 검사로 요침사 정도관리가 가능한지를 알 아보고자 하였다. $2.5 \%$ 글루타르알데히드를 보존액으로 하여 표본을 제작하였다. 보존제를 처리한 검체는 1 주일 간격으로 4 주간 세포의 형태학적 변형을 확인하였고, 이후 4주간은 보존여 부를 확인하였다. 요침사 슬라이드 제작 후 2개의 슬라이드를 제작하였으며, 하나는 냉장보관, 다른 하나는 실온 보관하여 검 
체의 형태학적 변형을 확인하였다. 글루타르알데히드는 요침 사를 냉장 보관하여 8주까지 보존하는 효과가 있었으며, 슬라이 드 제작 후에는 냉장 보관하여 3일까지 안정한 것으로 나타났 다. 또한 보존제 처리 후 슬라이드 제작하여 검사실간, 검사자간 판독을 비교한 결과 낮은 일치도를 보였다. 결론적으로 본 연구 를 통해 요침사 성분을 보존할 수 있으며, 실물을 통한 정도관리 및 교육용으로 활용될 것으로 기대된다.

Acknowledgements: This study was financially supported by the research fund of the Korean Association of External Quality Assessment Service, in 2016.

\section{Funding: None}

Conflict of interest: None

\section{REFERENCES}

1. Min WK, Kim JQ, Kwon HJ. A study for establishing the selective urine microscopical examination based on the results of dipstick test, visual inspection, and microscopical examination of urine sediments. J Lab Med Qual Assur. 1985;7(1):93-100.

2. Winkel P, Statland BE, Jorgensen K. Urine microscopy, an ill-defined method, examined by a multifactorial technique. Clin Chem. 1974;20(4):436-439.

3. Elin RJ, Hosseini JM, Kestner J, Rawe M, Ruddel M, Nishi HH. Comparison of automated and manual methods for urinalysis. Am J Clin Pathol. 1986;86(6):731-737.

4. Gadeholt H. Quantitative estimation of urinary sediment, with special regard to sources of error. Br Med J. 1964;1(5397): 1547-1549.

5. Koken T, Aktepe OC, Serteser M, Samli M, Kahraman A, Dogan N. Determination of cut-off values for leucocytes and bacteria for urine flow cytometer (UF-100) in urinary tract infections. Int Urol Nephrol. 2002;34(2):175-178.

6. Kim W, Choi YS, Lee YW, Han KS, Kim JH, Kim CW, et al. A study for the preservation of urinary sediments. Korean J Clin Pathol. 1986;6(2):293-297.

7. Jeon $\mathrm{CH}$, Lee AJ. Urinalysis and routine microscopy subcommittee, Korean Association of External Quality Assessment Service. Annual report on the external quality assessment scheme for urinalysis and faecal occult blood testing in Korea (2015). J Lab Med Qual Assur. 2016;38(3):120-128.

8. Komarova O, van der Meer W, Levtchenko E, Monnens L.
Effective chemical preservation of morphology of urinary erythrocytes. Pediatr Nephrol. 2003;18(7):665-666.

9. Hoshi M, Usami M, Inoue A, Ebihara M, Fukuta C. A new method for the long-term preservation of urinary sediment specimens. Japanese J Med Technol. 2016;65(5):505-512.

10. Anpalahan M. Birch D. Becker G. Chemical preservation of urine sediment for phase-contrast microscopic examination. Nephron. 1994;68(2):180-183.

11. del Rosario Rodríguez Moreno M, Rodríguez Moreno I, León MT, Boy M, Cowdry Agnieszka N. A new chemical preservative that permits analysis of urine sediment for light microscopic examination 12 h after emission. Nephron. 1999;82(1):65-71.

12. Coetzee J, van der Merwe CF. Effect of glutaraldehyde on the osmolarity of the buffer vehicle. J Microsc. 1985;138(1):99-105.

13. Clinical and Laboratory Standards Institute. Urinalysis; approved guideline-3rd ed, GP16-A3. Wayne, PA: Clinical and Laboratory Standards Institute; 2009. p5-25.

14. Delanghe J, Speeckaert M. Preanalytical requirements of urinalysis. Biochem Med (Zagreb). 2014;24(1):89-104.

15. Stankovic AK, Dilauri E. Quality improvements in the preanalytical phase: focus on urine specimen workflow. Clin Lab Med. 2008;28(2):339-350.

16. Kouri T, Vuotari L, Pohjavaara S, Laippala P. Preservation of urine for flow cytometric and visual microscopic testing. Clin Chem. 2002;48(6 Pt 1):900-905.

17. Ekşioğlu MK, Madenci ÖÇ, Yücel N, Elçi A, Turhan B, Orhan G, Orçun A. The effectiveness of BD vacutainer ${ }^{\circledR}$ plus urinalysis preservative tubes in preservation of urine for chemical strip analysis and particle counting. Biochem Med (Zagreb). 2016;26(2):224-232

18. Connor TH, Ward JB Jr, Legator MS. Absence of mutagenicity in the urine of autopsy service workers exposed to formaldehyde: factors influencing mutagenicity testing of urine. Int Arch Occup Environ Health. 1985;56(3):225-237.

19. Yum S, Amkraut A, Dunn T, Chin I, Killian D, Willis E. A disinfectant delivery system for control of micro-organisms in urine collection bags. J Hosp Infect. 1988;11(2):176-182.

20. Riddhimat R, Tantiniti P, Nilakul C. Boric acid in preservation of urine. J Med Assoc Thai. 1985;68(9):473-479.

21. Schumann GB, Schumann JL, Marcussen N. Cytodiagnostic urinalysis of renal and lower urinary tract disorders. 1st ed. New York: Igaku-Shoin; 1995. p13.

22. Bottini PV, Garlipp CR, Lauand JR, Lara Cioffi SG, Afaz SH, Lopes Prates R. Glomerular and non-glomerular haematuria: Preservation of urine sediment. Lab Med. 2005;36(10):647-649.

23. Lauer BA, Reller LB, Mirrett S, Ferris JA. Effect of chemical preservation of urine on routine urinalysis and non-culture tests for bacteriuria. Med Lab Sci. 1983;40(1):27-32. 